\title{
A comparative study between PI and cascaded sliding regulator based on rotor flux oriented control for photovoltaic pumping system and fuzzy MPPT optimization
}

Ines Zerimeche',

\author{
Abdeslam Haouam ${ }^{2}$, \\ Fateh Mehazzem ${ }^{3}$, \\ Khalil Nabti ${ }^{1}$, \\ Rachid Chenni $^{1,2}$ \\ ${ }^{1}$ Department of Electrotechnique, \\ Mentouri University of Constantine 1, Algeria \\ Email:zerimech.inas@hotmail.fr, \\ idor2003@yahoo.fr, rachid.chenni@umc.edu.dz \\ ${ }^{2}$ Department of Electronique, \\ MODERNa Laboratory, \\ Mentouri University of Constantine 1, Algeria \\ Email:salimhaouam@gmail.com

In this paper, a comparative study between the PI and the cascaded sliding regulator is made, based on rotor flux oriented control for the photovoltaic pumping system. In order for the motor-pump to be always optimized and operate at the maximum power for each change of illumination or temperature, it is necessary to integrate the MPPT tracking system, we used the fuzzy MPPT technique. The three-phase converter is controlled by the technique of vector width modulation (SVPWM), characterized by low response time and oscillation. Simulations of the proposed structures are validated under Matlab/Simulink. The obtained results show the superiority of cascaded sliding mode control combined with fuzzy MPPT technique, they confirm the effectiveness of this control structure in terms of parametric robustness and ensure proper operation over the entire speed range.

Keywords: photovoltaic generator, pumping system, rotor flux oriented control, PI and sliding regulators, and fuzzy MPPT

\section{INTRODUCTION}

The energy production is a challenge of great importance for the next years. It is strongly related to the energy needs of the industrialized companies. Nowadays, most of the worldwide production of electrical energy is produced by combustion of nonrenewable resources like oil, natural gas and coal. The consumption of these sources gives place to gas emissions with the greenhouse effect, which provide the increase of pollution [1].

Development of green sources based on renewable energy is more and more solicited by both energy producers and public authorities. Nowadays, the photovoltaic generator (GPV) is considered as one of the most attractive green sources of electric energy. The photovoltaic cell is the basic electronics component of a photovoltaic generator using 
the photoelectric effect to convert the electromagnetic waves emitted by the sun into electricity. Several cells connected between them form a photovoltaic solar module [2].

The photovoltaic pumping system consists of collecting solar energy via photovoltaic panels to produce electricity which supplies an electric pump to ensure drainage of water [3]. In the direct coupling of the pumping system with the GPV, the operating point is sometimes very far from the maximum power point (PPM), in particular for low illumination. An adaptation stage, comprising one or more static converters, makes it possible to transform the continuous electrical quantities into quantities adapted to the load. This stage can be controlled by one or more control laws in order to optimize the power produced by the generator. In this sense, and in order to optimize the power supplied by the GPV, a three-phase converter must be introduced between the source and the AC load. This adaptation stage must be associated with a command to search for the maximum power point.

The energy delivered by the photovoltaic cells depends on a complex equation relating the solar radiation, the temperature and the total resistance of the circuit, which leads to a nonlinear output power. The goal is to get the maximum power, through the MPPT algorithm [4]. MPPT based on the fuzzy logic technique allows performance optimization of the photovoltaic production system according to illumination variation, the advantage of which is to adapt disturbance in order to optimize time response with precision [5].

The photovoltaic pumping system is composed of a GPV, a power converter and a motor pump system. Nowadays, induction motors (IM) have taken place of DC motors because of their good performance: reliability, robustness, low cost and simple maintenance. On the other hand, the control of induction motors is very complex. This complexity is due mainly to the following reasons: an analytical model of IM is nonlinear, multivariable and strongly coupled. The presence of parametric uncertainties gives an additional constraint. Subsequently, several nonlinear control techniques have been proposed for IM control. Sliding mode control, which is characterized by simplicity of construction and robustness to external disturbances [6], is here used as regulator to simplify the rotor flux oriented control scheme and make it similar to a DC machine.

In this paper, the photovoltaic pumping system is studied. To operate GPV at its maximum power condition, an efficient fuzzy MPPT technique is used. A VSI is used to convert the DC power into the $\mathrm{AC}$ power to feed a three-phase induction motor driving a water pump. To control this IM a comparative study between a PI and a cascaded sliding regulator is made based on rotor flux oriented control structure. In this structure, the nonlinear adaptive speed and rotor flux control algorithm combined with field orientation for IM drive has been developed.

\section{Nomenclature:}

\begin{tabular}{cc}
\hline \multicolumn{1}{c}{ I } & Current supplied by the cell \\
\hline$I_{p h}$ & Photo current \\
\hline$T$ & Temperature \\
\hline$V$ & Voltage at the cell terminals \\
\hline$R_{s}$ & Resistance series \\
\hline$I_{s}$ & Saturation current \\
\hline$\omega$ & Mechanical pulsation \\
\hline$\omega_{s}$ & Stator pulsation \\
\hline$\omega_{r}$ & Slip pulse \\
\hline$\rho$ & Density of water $1000 \mathrm{~kg} / \mathrm{m}^{3}$ \\
\hline$g$ & Gravity acceleration $9.81 \mathrm{~m} / \mathrm{s}$ \\
\hline$Q$ & Water flow \\
\hline$H$ & Total manometric head \\
\hline$k_{r}$ & Proportionality coefficients $[\mathrm{Nm} /(\mathrm{rad} . \mathrm{s}-1) 2]$ \\
\hline$C_{s}$ & Static torque, very small \\
\hline
\end{tabular}

\section{PROPOSED SYSTEM CONFIGURATION}

\section{Global structure design}

The different levels of the proposed photovoltaic pumping system are illustrated in Fig. 1. The general structure mainly includes a photovoltaic generator, a voltage inverter transforming the direct voltage delivered by the GPV into an alternating voltage by forcing it to operate at the maximum power delivered by the panel, and a centrifugal pump driven by an induction motor.

\section{Solar PV generator}

The photovoltaic cell is represented by the 'standard' model with a diode. This model has one less 


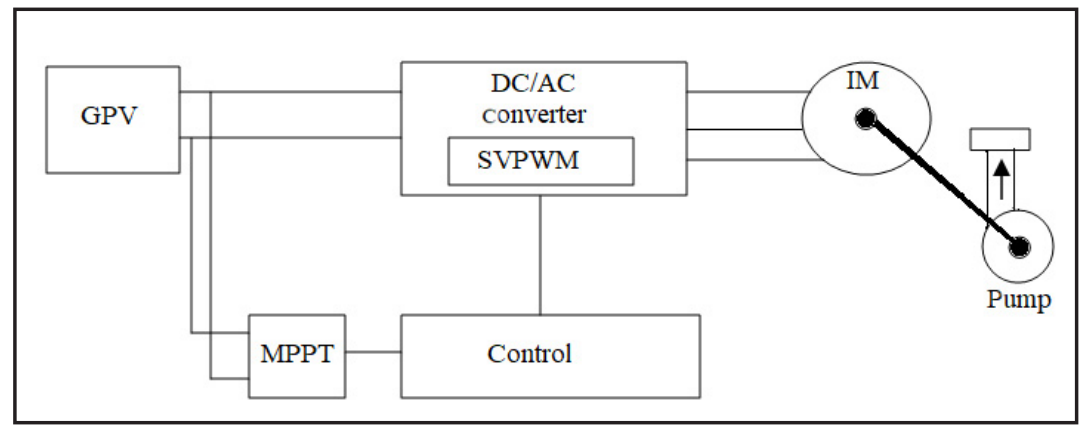

Fig. 1. Global structure design for PV water pumping

diode compared to the two-diode model. Figure 2 illustrates the one-diode model of the photovoltaic cell [4].

The expression of current I then becomes

$$
I=I_{p h}-I_{s}\left(e^{\left(\frac{q\left(V+R_{s} I\right)}{n K T}\right)}-1\right)-\frac{V+I^{*} R_{s}}{R_{p}} .
$$

The parallel resistance $R_{p}$ is very large compared to the series resistance $R_{s}$, the parallel resistance generally represents the leakage current of the junction, being generally very important; one can neglect it on the equivalent diagram. This model, which is widely used, becomes easier to study. The simplified model of the photovoltaic cell is shown in Fig. 3 [2, 7].

$$
\begin{aligned}
& \text { So, } \\
& I=I_{p h}-I_{s}\left(e^{\left(\frac{q\left(V+R_{s} I\right)}{n K T}\right)}-1\right) .
\end{aligned}
$$

\section{Modelling under Simulink}

In order to have a simple model to use, we proceeded to the implementation of a model of the photovoltaic panel under Matlab-Simulink which will be used in the continuation of our work. The model, based on Equation 2, has two input parameters (temperature and illumination) and two output parameters (voltage and current). Figure 4 illustrates the model of the photovoltaic panel.

In our study, the TE500 panel is chosen as a simulation model under MATLAB. The module

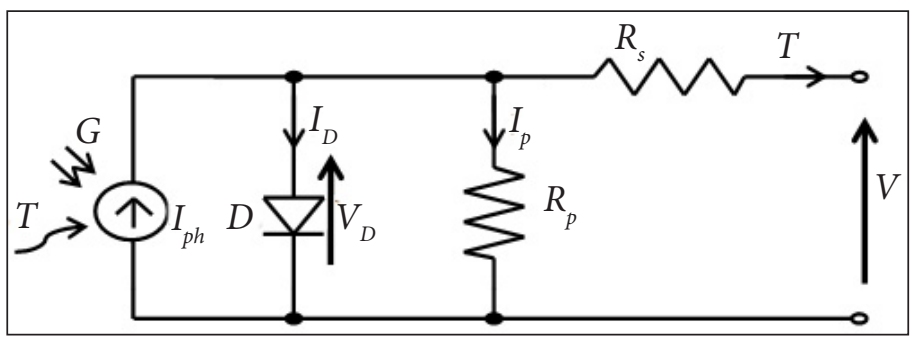

Fig. 2. Electric model equivalent to a diode of the photovoltaic cell

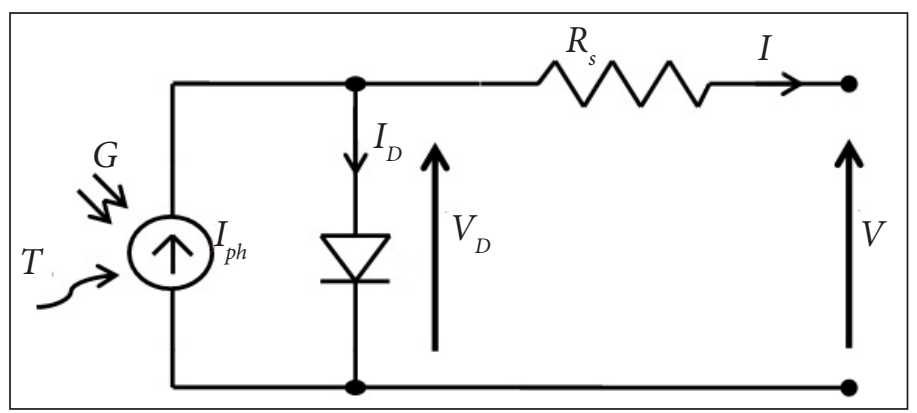

Fig. 3. A simplified equivalent electric model of the photovoltaic cell 


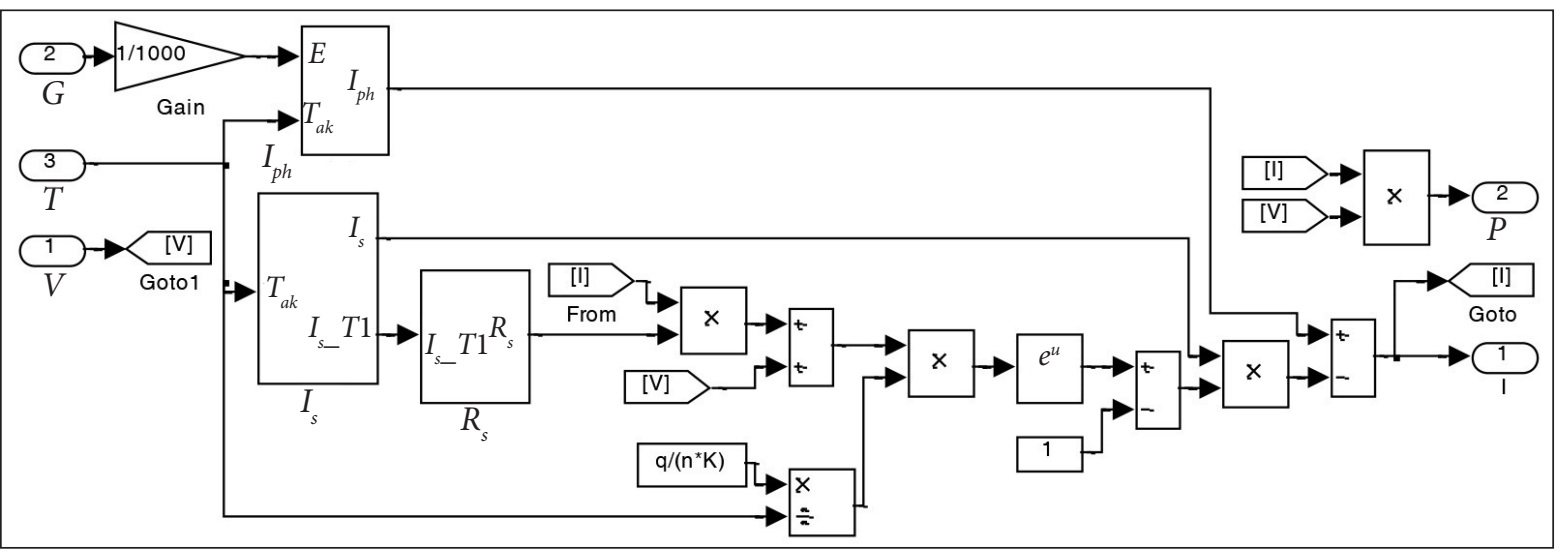

Fig. 4. The TE500 module cell

is made up of 36 multi-crystalline silicon solar cells in series and provides $60 \mathrm{~W}$ of the maximum rated power.
The influence of climatic parameters on the optimal operation of the PV solar panel can be represented by

\section{A. Influence of temperature}

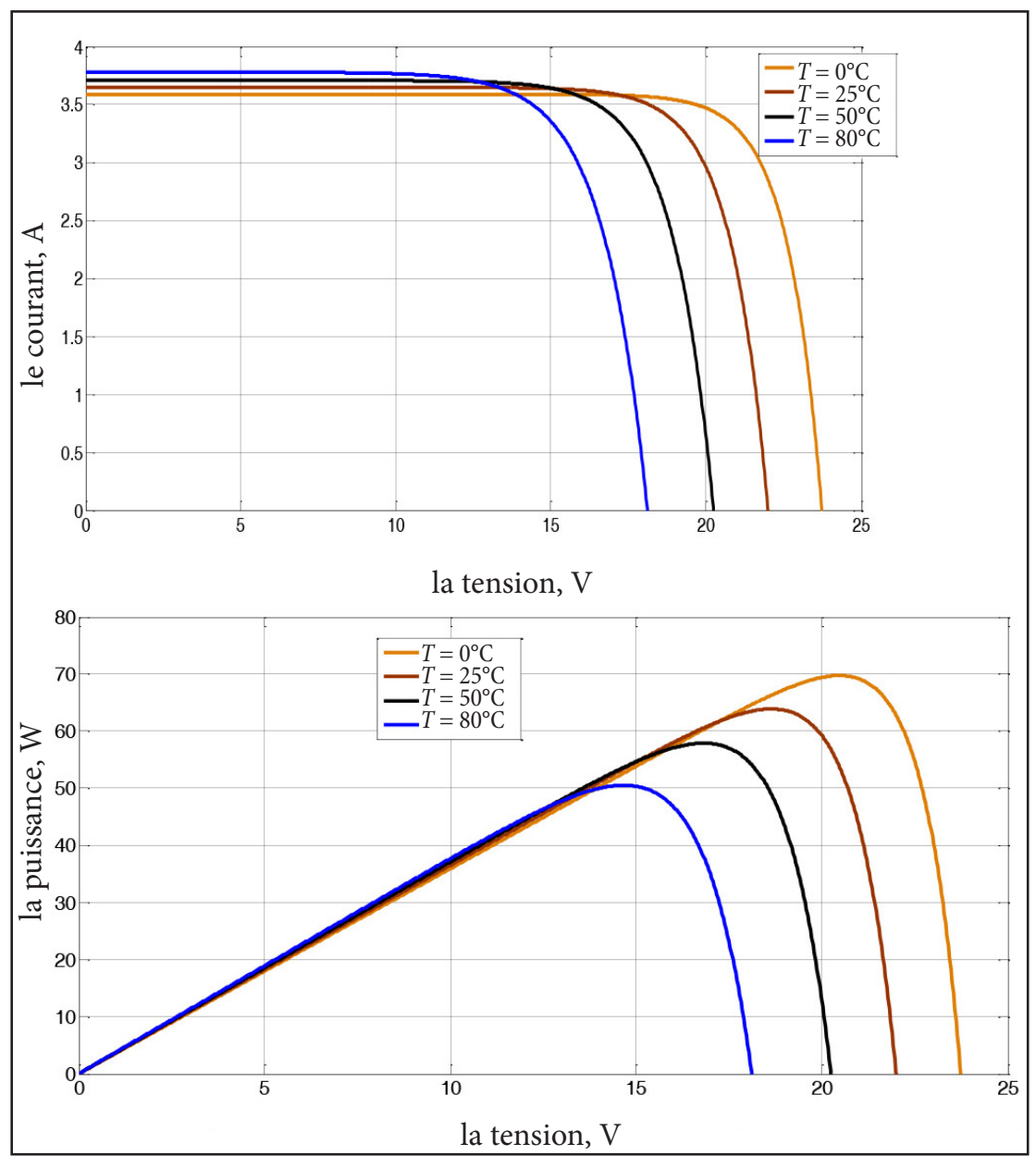

Fig. 5. I(V) and $P(V)$ characteristics for a variable temperature and an illumination of $1 \mathrm{~kW} / \mathrm{m}^{2}$ 
The most significant effect of increasing the cell temperature is on the open circuit voltage, which decreases with increasing temperature; thus the efficiency of the cell decreases and the current gains a little intensity when the temperature increases. This can be explained by better absorption of light. The increase in current can be neglected at the point of maximum power and even at the overall behaviour of the cell.

\section{B. Influence of irradiation}

The open circuit voltage increases logarithmically by increasing solar radiation, while the short circuit current increases linearly. Curves I(V) shift towards increasing values allowing the module to produce greater electrical power.

\section{DC-AC converter}

The inverter used consists of transistors of the IGBT type controlled by the technique of vector width modulation (SVPWM) whose principle consists in imposing voltages, chopped at a fixed frequency, at the terminals of the machine [8].

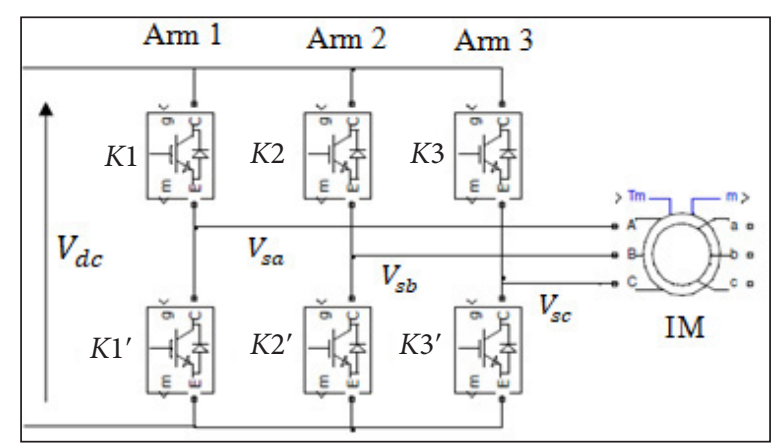

Fig. 7. DC-AC converter

$$
\begin{aligned}
& {\left[V_{s a b c}\right]=\left[\begin{array}{l}
V_{s a} \\
V_{s b} \\
V_{s c}
\end{array}\right]=\frac{1}{3} \cdot V_{d c} \cdot\left[\begin{array}{ccc}
2 & -1 & -1 \\
-1 & 2 & -1 \\
-1 & -1 & 2
\end{array}\right] \cdot\left[\begin{array}{l}
C_{1} \\
C_{2} \\
C_{3}
\end{array}\right]} \\
& =V_{d c} \cdot\left[T_{s}\right] \cdot\left[C_{k}\right], \\
& {\left[C_{k}\right]=\left[C_{1} C_{2} C_{3}\right]^{T} ;\left[V_{s a b c}\right]=\left[V_{s a} V_{s b} V_{s c}\right]^{T} .}
\end{aligned}
$$

The relation between the reference mark abc and the stationary reference mark $d-q$ is shown in the following figure.

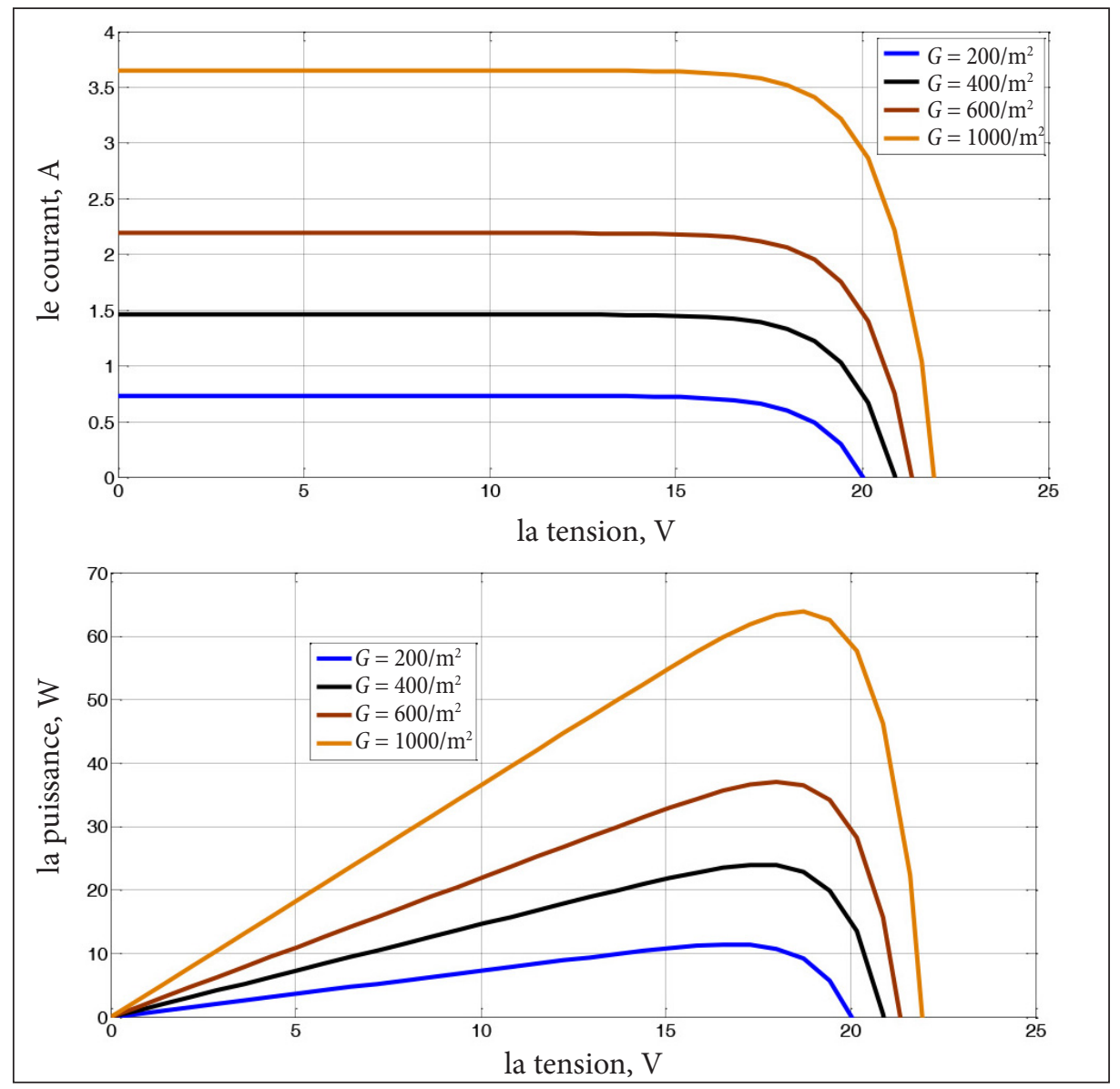

Fig. 6. $I(V)$ and $P(V)$ characteristics for variable illumination and a temperature of $25^{\circ} \mathrm{C}$ 


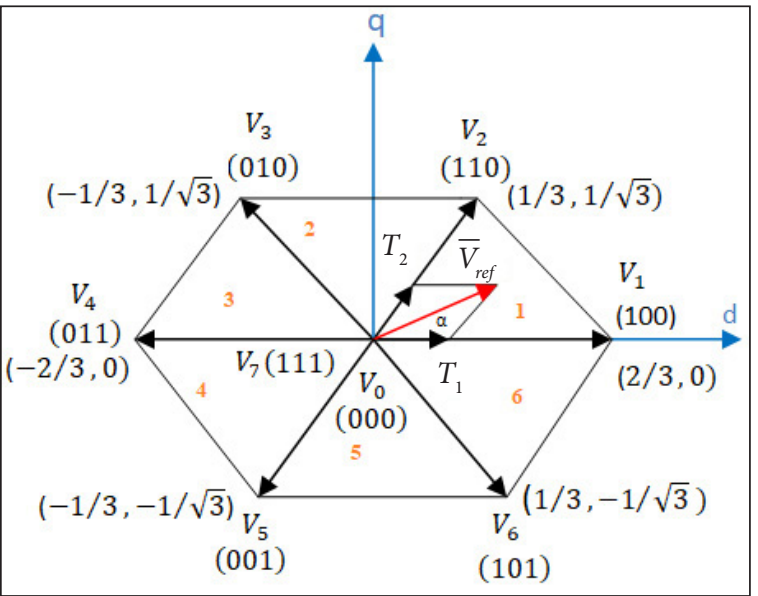

Fig. 8. Reference spatial vector generation using a switching state vector

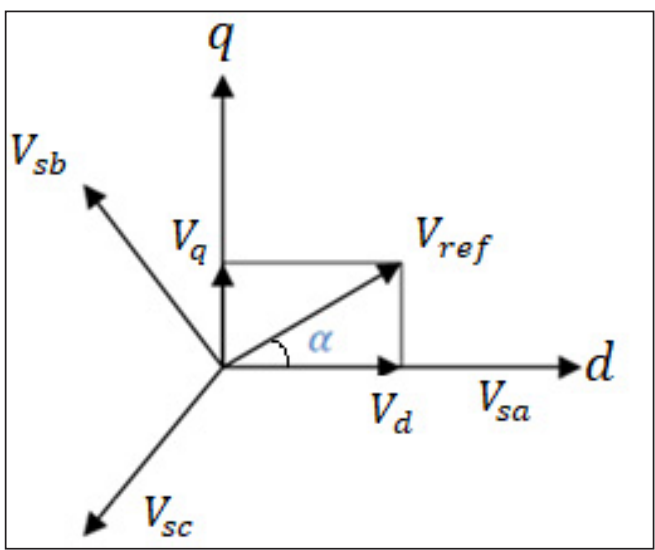

Fig. 9. Relation between the reference mark $a b c$ and the stationary mark $d-q$

$$
\begin{aligned}
& \vec{V}_{r e f}=\frac{2}{3}\left(V_{s a}+V_{s b} e^{j \frac{2 \pi}{3}}+V_{s c} e^{j \frac{4 \pi}{3}}\right) \\
& V_{d}=V_{s a}-\frac{1}{2} V_{s b}-\frac{1}{2} V_{s c}, \\
& V_{q}=0+\frac{\sqrt{3}}{2} V_{s b}-\frac{\sqrt{3}}{2} V_{s c}, \\
& V_{r e f}=\sqrt{V_{d}^{2}+V_{q}^{2}} \\
& \alpha=\tan ^{-1}\left(\frac{V_{q}}{V_{d}}\right) .
\end{aligned}
$$

The general expression to change time in any sector can be found as follows:

$$
\begin{aligned}
& T_{1}=\frac{\sqrt{3} T_{z} V_{r e f}(\sin n 60 \cdot \cos \alpha-\cos 60 \cdot \sin \alpha)}{V_{d c}}, \\
& T_{2}=\frac{\sqrt{3} T_{z} V_{r e f}(-\cos \alpha \cdot \sin (n-1) 60}{V_{d c}}+ \\
& \frac{\sin \alpha \cdot \cos (n-1) 60)}{V_{d c}}, \\
& T_{z}=T_{1}+T_{2}+T_{0} . \text { Thus } T_{0}=T_{z}-T_{1}-T_{2} .
\end{aligned}
$$

Table 1. Switching sequences

\begin{tabular}{c|c|c|c|c|c|c|c}
\hline \multirow{2}{*}{ Sector } & \multicolumn{7}{|c}{ Switching segment } \\
\cline { 2 - 7 } & $\mathbf{1}$ & $\mathbf{2}$ & $\mathbf{3}$ & $\mathbf{4}$ & $\mathbf{5}$ & $\mathbf{6}$ & $\mathbf{7}$ \\
\hline 1 & $\vec{V}_{0}$ & $\vec{V}_{1}$ & $\vec{V}_{2}$ & $\vec{V}_{7}$ & $\vec{V}_{2}$ & $\vec{V}_{1}$ & $\vec{V}_{0}$ \\
\hline 2 & $\vec{V}_{0}$ & $\vec{V}_{3}$ & $\vec{V}_{2}$ & $\vec{V}_{7}$ & $\vec{V}_{2}$ & $\vec{V}_{3}$ & $\vec{V}_{0}$ \\
\hline 3 & $\vec{V}_{0}$ & $\vec{V}_{3}$ & $\vec{V}_{4}$ & $\vec{V}_{7}$ & $\vec{V}_{4}$ & $\vec{V}_{3}$ & $\vec{V}_{0}$ \\
\hline 4 & $\vec{V}_{0}$ & $\vec{V}_{5}$ & $\vec{V}_{4}$ & $\vec{V}_{7}$ & $\vec{V}_{4}$ & $\vec{V}_{5}$ & $\vec{V}_{0}$ \\
\hline 5 & $\vec{V}_{0}$ & $\vec{V}_{5}$ & $\vec{V}_{6}$ & $\vec{V}_{7}$ & $\vec{V}_{6}$ & $\vec{V}_{5}$ & $\vec{V}_{0}$ \\
\hline 6 & $\vec{V}_{0}$ & $\vec{V}_{1}$ & $\vec{V}_{6}$ & $\vec{V}_{7}$ & $\vec{V}_{6}$ & $\vec{V}_{1}$ & $\vec{V}_{0}$ \\
\hline
\end{tabular}

\section{Induction motor}

In a frame with rotating field $\left(\theta_{s}=\theta+\theta_{r}\right) \Rightarrow$ $\left(\omega_{s}=\omega+\omega_{r}\right)$, the model of the induction motor is given by [9]

$$
\begin{aligned}
& \frac{d}{d t} I_{s d}= \\
& \frac{1}{\sigma L_{s}}\left[\begin{array}{c}
-\left(R_{s}+\frac{M_{s r}^{2} R_{r}}{L_{r}^{2}}\right) I_{s d}+\left(\omega_{s} \sigma L_{s}\right) I_{s q}+\left(\frac{M_{s r} R_{r}}{L_{r}^{2}}\right) \Phi_{r d} \\
+\left(\frac{M_{s r}}{L_{r}} \omega\right) \Phi_{r q}+V_{s d}
\end{array}\right], \\
& \frac{d}{d t} I_{s q}= \\
& \frac{1}{\sigma L_{s}}\left[\begin{array}{c}
-\left(\omega_{s} \sigma L_{s}\right) I_{s d}-\left(R_{s}+\frac{M_{s r}^{2} R_{r}}{L_{r}^{2}}\right) I_{s q}-\left(\frac{M_{s r}}{L_{r}} \omega\right) \Phi_{r d} \\
+\left(\frac{M_{s r} R_{r}}{L_{r}^{2}}\right) \Phi_{r q}+V_{s q}
\end{array}\right], \\
& \frac{d}{d t} \Phi_{r d}=\left(\frac{M_{s r} R_{r}}{L_{r}}\right) I_{s d}-\left(\frac{R_{r}}{L_{r}}\right) \Phi_{r d}+\left(\omega_{s}-\omega\right) \Phi_{r q}, \\
& \frac{d}{d t} \Phi_{r q}=\left(\frac{M_{s r} R_{r}}{L_{r}}\right) I_{s q}-\left(\frac{R_{r}}{L_{r}}\right) \Phi_{r q}-\left(\omega_{s}-\omega\right) \Phi_{r d},
\end{aligned}
$$


such as

$\sigma=1-\frac{M_{s r}^{2}}{L_{s} L_{r}}, \omega=p \Omega, \omega_{r}=\omega_{s}-\omega$.

The electromagnetic torque equation is given by

$T_{e}=p \frac{M_{s r}}{L_{r}}\left(\Phi_{r d} I_{s q}-\Phi_{r q} I_{s d}\right)$.

And the mechanical equation becomes

$$
\begin{aligned}
& \frac{d \Omega}{d t}= \\
& \frac{1}{J}\left[p \frac{M_{s r}}{L_{r}}\left(\Phi_{r d} I_{s q}-\Phi_{r q} I_{s d}\right)-T_{r}-F \Omega\right] .
\end{aligned}
$$

\section{Induction water pump}

A pump is a machine that provides energy to a fluid according to its displacement from a point to another. The general expression of the hydraulic power in Watt is given as follows [10]:

$$
P_{H}=\rho \cdot g \cdot Q \cdot H \text {. }
$$

The centrifugal pump applies a load torque proportional to the square of the rotational speed of the engine

$$
T_{r}=k_{r} \omega^{2}+C_{s}
$$

Mechanical power $P_{\text {mec }}$, which must receive the pump to ensure the hydraulic power (mechanical power necessary to the pump), is expressed in $\mathrm{kW}$ and depends on the efficiency $\eta_{p}$ of the pump:

$$
P_{m e c}=\frac{P_{H}}{\eta_{p}}
$$

And the relationship between the mechanical power of the pump and the speed is given by

$$
P_{\text {mec }}=k_{p} \omega^{3} \text {. }
$$

\section{CONTROL OF THE PROPOSED SYSTEM}

\section{Fuzzy MPPT algorithm}

Fuzzy logic based MPPT is developed to obtain the MPP of a PV system [11]. The diagram of the fuzzy controller is shown in the next figure.

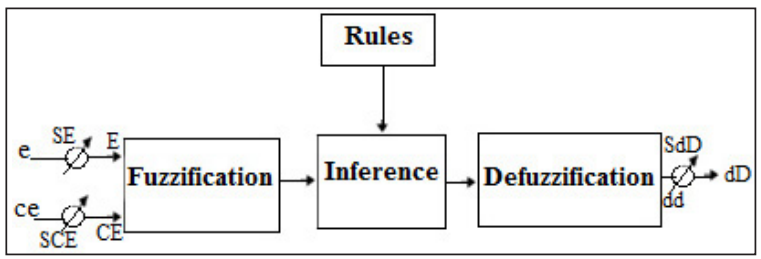

Fig. 10. General structure of a fuzzy controller. SE, SCE: input gains; $\mathrm{SdD}$ : output gain; $\mathrm{E}$ : the error between $d P / d V$ and $\Delta \mathrm{E}$ : the variation of the error

These methods make it possible to formulate a set of decisions in linguistic terms, using fuzzy sets to describe the amplitudes of the error, its variation and the appropriate command. By combining these rules, we can draw decision tables allowing to give the values of the controller output corresponding to the situations of interest.

Table 2. A flowchart of the fuzzy MPPT technique

\begin{tabular}{ccccccccccc}
\hline EE & NG & NM & NP & $\mathbf{Z}$ & PP & PM & PG \\
\hline NG & NG & NG & NG & NG & NM & NP & Z \\
\hline NM & NG & NG & NG & NM & NP & Z & PP \\
\hline NP & NG & NG & NM & NP & Z & PP & PM \\
\hline$Z$ & NG & NM & NP & Z & PP & PM & PG \\
\hline PP & NM & NP & Z & PP & PM & PG & PG \\
\hline PM & NP & Z & PP & PM & PG & PG & PG \\
\hline PG & $Z$ & PP & PM & PG & PG & PG & PG \\
\hline
\end{tabular}

The architecture under the Matlab-Simulink of the MPPT system and Photovoltaic panel is the following:

Two values $E$ and $\Delta E$ then pass by a filter of saturation to make sure that $E$ and $\Delta E$ will be well included in the universe of the speech defined in the fuzzy partitions (it is about the interval [-10, 10] in both cases). The criteria input the fuzzy controller.

This last product, an increment $\Delta V$, has to add to the value $V$ of the input.

During the development of the MPPT, we have met a problem of division by 0 in the determination of $d P / d V$. Indeed, $V$ is null at the beginning and consequently $d V$ as well. The selected solution is presented in the diagram in Fig. 13. 


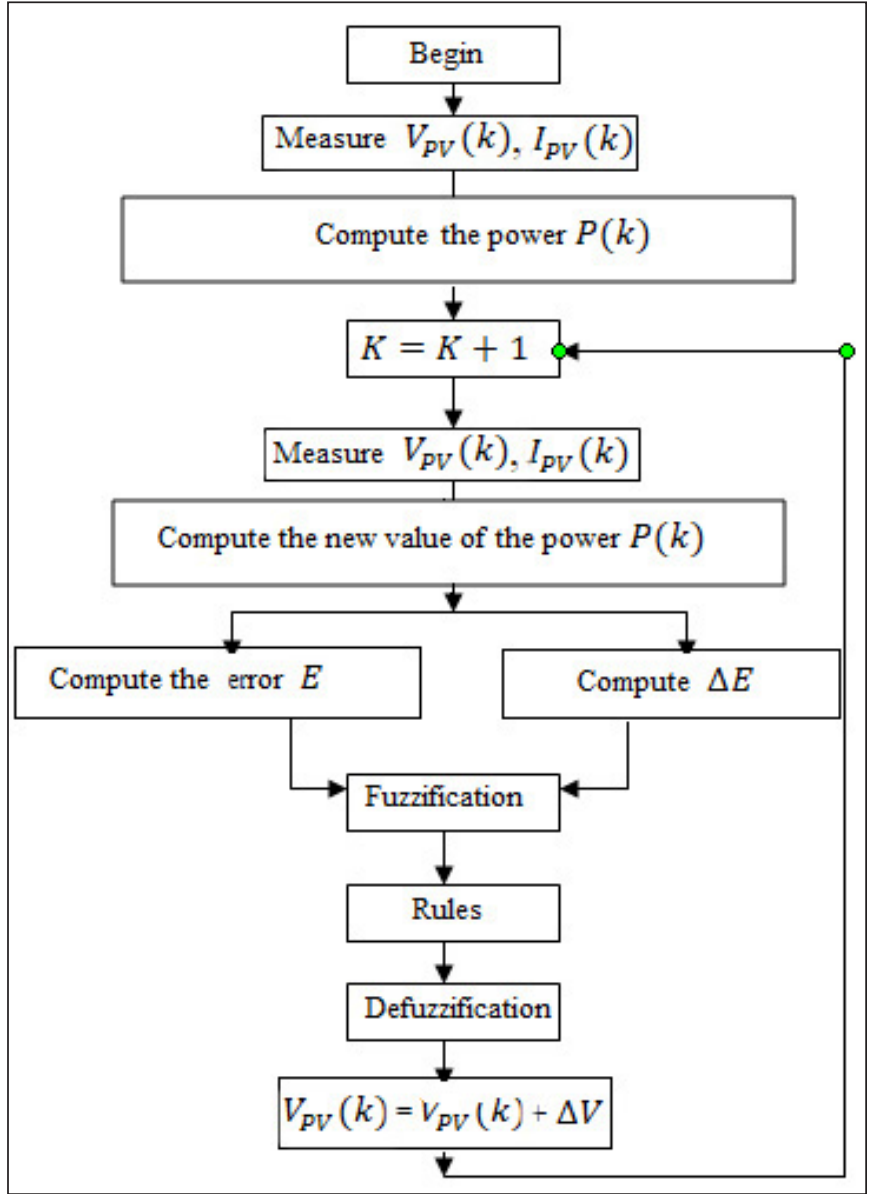

Fig. 11. A flowchart of the fuzzy MPPT technique

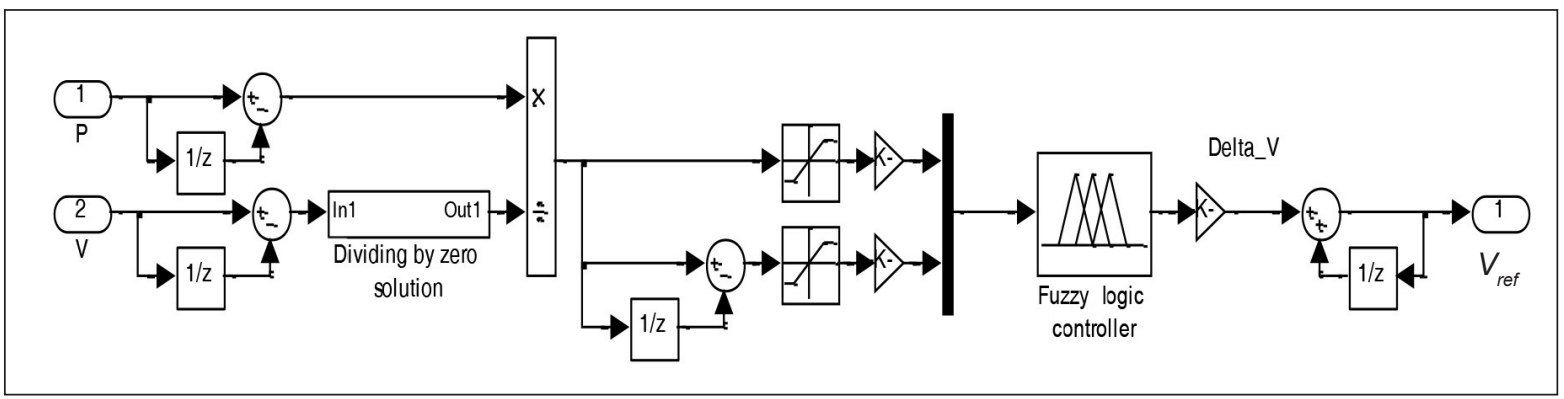

Fig. 12. Structure of the photovoltaic system and fuzzy MPPT under Matlab-Simulink

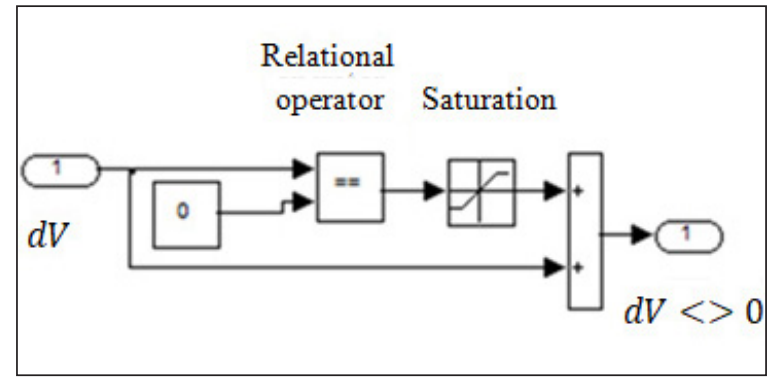

Fig. 13. System architecture to solve the divide by zero problems
The algorithm for finding the maximum operating point will be done as follows:

- Determine, for a given illumination and temperature, the characteristic $I(V)$ of the generator and maximum power point $\left(V_{p m}, I_{p m}, P_{p m}\right)$.

- Determination of the optimal reference speed of the machine according to the characteristics of the photovoltaic generator, which are themselves a function of the illumination and the temperature, through the following procedure: 
We have Equation (18):

$P_{\text {méc }}=k_{p} \cdot \omega^{3}$.

We know that

$$
P_{\text {méc }}=\eta_{p} \cdot P_{m}
$$

where $\eta_{p}$ is the pump yield, and $P_{m}$ is the engine power.

The power of the engine also can be given according to the yield of this last as follows:

$$
P_{m}=\eta_{m} \cdot P_{i}
$$

Here $\eta_{m}$ is the engine yield, and $P_{c}$ is the power at the output of the converter.

Likewise,

$$
P_{c}=\eta_{c} \cdot P_{p m}=\eta_{c} \cdot V_{p m} \cdot I_{p m}
$$

where $P_{p m}$ is the maximum power that the photovoltaic generator can deliver.

Therefore,

$$
P_{m e ́ c}=k_{p} \omega^{3}=\eta_{p} \cdot \eta_{m} \cdot \eta_{c} \cdot V_{p m} \cdot I_{p m}
$$

So the optimal reference speed, a function of maximum values of the current and voltage, is

$$
\omega_{o p t}=\sqrt[3]{\frac{\eta_{p} \cdot \eta_{m} \cdot \eta_{c} \cdot V_{p m} \cdot I_{p m}}{k_{p}}}
$$

where $\eta_{c} \cdot \eta_{m} \cdot \eta_{p}$ are, respectively, the yield of the inverter, the engine and the pump.

\section{Flux oriented control (FOC)}

The objective of the control by orientation of the flux of inductions machines is to improve their dynamic and static behaviour, using a control structure similar to that of a DC machine. The axis component $\mathrm{d}$ of the stator current plays the role of excitation and allows one to adjust the value of the flux in the machine, and the axis component $q$ plays the role of induced current and allows one to control the torque. This command called 'Flux Oriented Control' is based on a judicious choice of the reference mark ( $d$, $q)$. The latter is oriented so that the axis $d$ is in the phase with the desired flux.
The expression of the torque is then simplified and is only a function of the flux and quadrature current. So, keeping the flux at a constant value, the torque only depends on the quadrature component of the stator current $I_{s q}$ and can be controlled by this one.

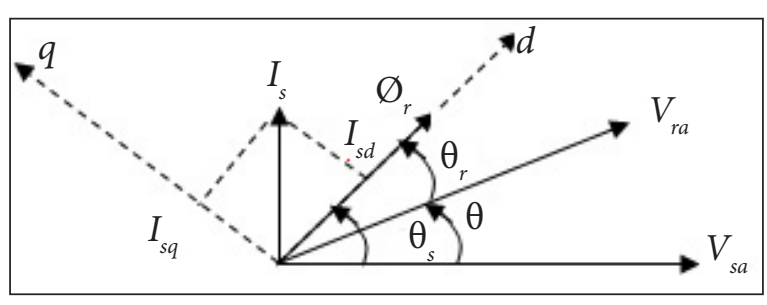

Fig. 14. Rotor flux orientation

So,

$$
T_{e}=p \frac{M_{s r}}{L_{r}}\left(\Phi_{r d} I_{s q}\right)
$$

\section{General expression of the control}

Фr flux being oriented on the axis $d$, therefore the model of the induction motor enables us to express Vsd, Vsq, Isd and $\omega s$, with $\Phi_{\mathrm{rq}}=0 \Rightarrow \frac{\mathrm{d} \Phi_{\mathrm{rq}}}{\mathrm{dt}}=0$ :

$$
\left\{\begin{array}{c}
V_{s d}=\left(\sigma L_{s}\right) \frac{d}{d t} I_{s d}+\left(R_{s}+\frac{M_{s r}^{2} R_{r}}{L_{r}^{2}}\right) I_{s d}- \\
\left(\omega_{s} \sigma L_{s}\right) I_{s q}-\left(\frac{M_{s r} R_{r}}{L_{r}^{2}}\right) \Phi_{r} \\
V_{s q}=\left(\sigma L_{s}\right) \frac{d}{d t} I_{s q}+\left(R_{s}+\frac{M_{s r}^{2} R_{r}}{L_{r}^{2}}\right) I_{s q}+ \\
\left(\omega_{s} \sigma L_{s}\right) I_{s d}+\left(\frac{M_{s r}}{L_{r}} \omega\right) \Phi_{r} \\
I_{s d}=\left(\frac{T_{R} s+1}{M_{s r}}\right) \Phi_{r} \\
\omega_{s}=\left(\frac{M_{s r}}{T_{R}}\right) \frac{I_{s q}}{\Phi_{r}}+\omega \\
T_{R}=\frac{L_{r}}{R_{r}}, \omega_{r}=\left(\frac{M_{s r}}{T_{R}}\right) \frac{I_{s q}}{\Phi_{r}} \text { and } \omega_{s}=\frac{d}{d t} \theta_{s} .
\end{array}\right.
$$


$V_{s d}$ and $V_{s q}$ influence at the same time $I_{s d}$ and $I_{s q}$, thus the flow and the couple. It is thus necessary to carry out a decoupling:

$$
\begin{aligned}
& \left\{\begin{array}{l}
V_{s d}=V_{s d 1}-e_{s q} \\
V_{s q}=V_{s q 1}-e_{s d}
\end{array}\right. \\
& \left\{\begin{array}{c}
e_{s d}=\left(\omega_{s} \sigma L_{s}\right) I_{s q}+\left(\frac{M_{s r} R_{r}}{L_{r}^{2}}\right) \Phi_{r} \\
e_{s q}=-\left(\omega_{s} \sigma L_{s}\right) I_{s d}-\left(\frac{M_{s r}}{L_{r}}\right) \Phi_{r} \\
V_{s d 1}=\left(\sigma L_{s}\right) \frac{d}{d t} I_{s d}+\left(R_{s}+\frac{M_{s r}^{2} R_{r}}{L_{r}^{2}}\right) I_{s d} \\
V_{s q 1}=\left(\sigma L_{s}\right) \frac{d}{d t} I_{s q}+\left(R_{s}+\frac{M_{s r}^{2} R_{r}}{L_{r}^{2}}\right) I_{s q}
\end{array}\right.
\end{aligned}
$$

Therefore, the functional diagram correspondent of the control is represented in Fig. 15.

\section{RESULTS AND DISCUSSION}

The simulation results have been obtained under a constant rotor flux $=0.8$.
Figure 16(c) shows the increased power effect, caused by an increase in sunshine, which causes a change of the maximum power point (MPP) for the proposed fuzzy MPPT algorithm with the increase in current and speed. Once the sunshine stabilizes, the power returns to its state of stability with a low ripple. It can be seen that, despite the change of sunshine, the fuzzy MPPT algorithm has kept the optimal values of the power. These results demonstrate very clearly that the proposed scheme (fuzzy MPPT controller) exhibits a fast dynamic response and a stable steady-state output power, even when the weather conditions are rapidly changed.

From the curves representing the speed and the torque we can distinguish the effectiveness of the indirect flux oriented control (IFOC) combined with an intelligent tracking technique (fuzzy MPPT), the results presented a tracking of the speed to its reference with a robustness with respect to the changes of the climatic conditions, with a shorter transitory mode.

\section{Cascade sliding mode control}

In order to obtain a better performance for the IM-pump control, the sliding mode control structure is used to replace the traditional nonlinear feedback PI of the control system for rotor speed and rotor flux regulation.

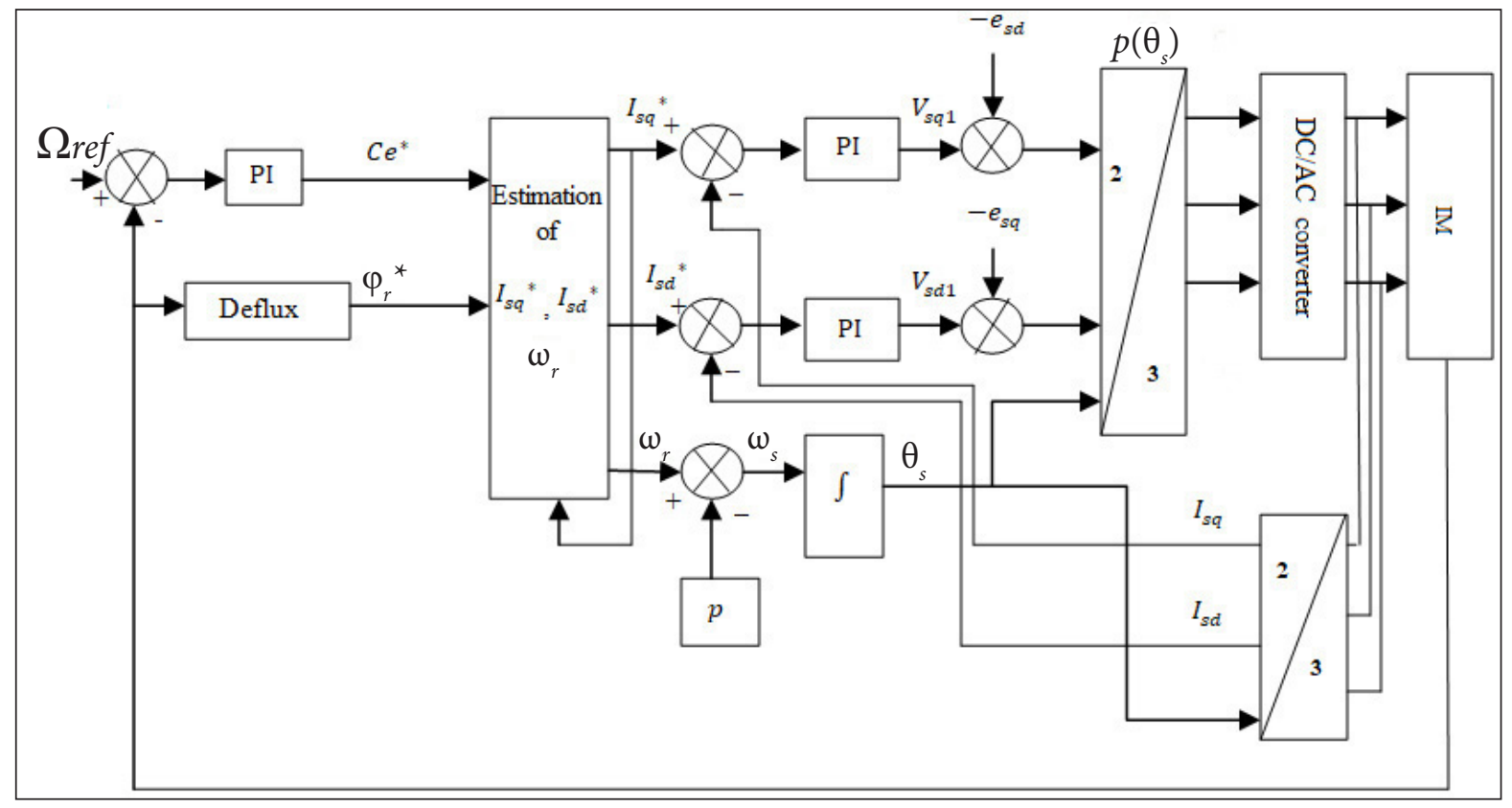

Fig. 15. A bloc structure diagram of the IM control 


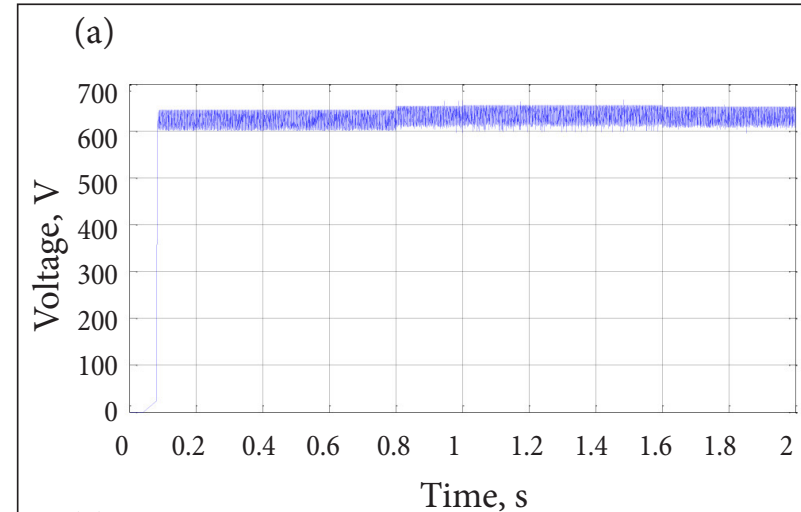

(b)

(c)
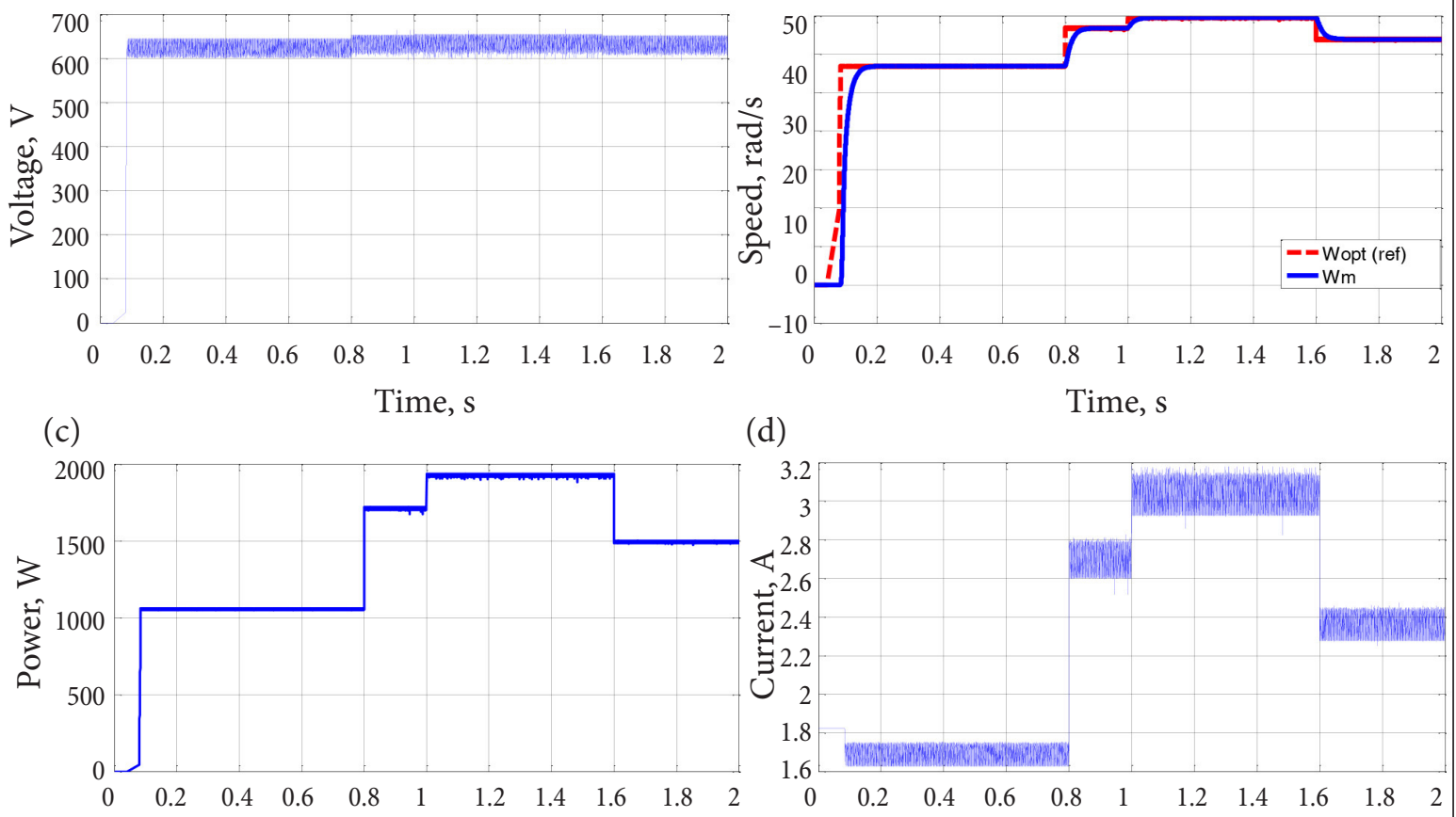

(d)

Time, s

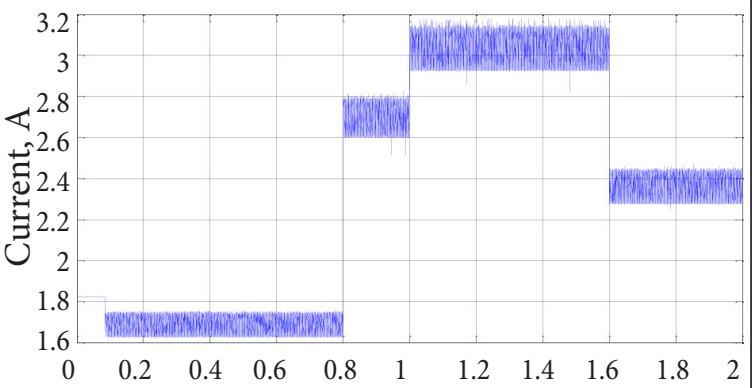

(e)

Time, s

Time, $s$

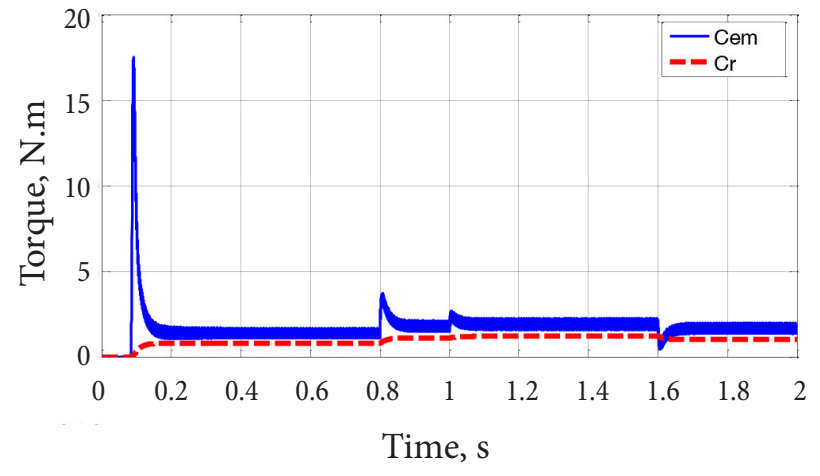

Fig. 16. PV system performances with variable irradiation

The application of the sliding mode algorithm consists of many steps:

\section{Step 1. Design of the switching surfaces}

We have four PI controllers; we will define four sliding surfaces:

$$
\begin{aligned}
& S_{1}(\omega)=\omega_{r e f}-\omega, \\
& S_{2}\left(c=\emptyset_{r d r e f}-\emptyset_{r d^{\prime}}\right. \\
& S_{3}\left(I_{s q}\right)=I_{s q r e f}-I_{s q^{\prime}} \\
& S_{4}\left(I_{s d}\right)=I_{s d r e f}-I_{s d^{\circ}}
\end{aligned}
$$

\section{Step 2. Control design}

Sliding mode controller's law has the form

$$
u_{c}=u_{e q}+u_{n},
$$

where $u_{e q}$ is the so-called equivalent control, and $u_{n}$ is the so-called nominal control.

\section{Rotor flux regulation}

$$
\begin{aligned}
& \dot{S}_{2}\left(\varnothing_{r d}\right)=0 \Rightarrow I_{s d e q}=\frac{\varnothing_{r d}+T_{R} \dot{\varnothing}_{r d r e f}}{M_{s r}}, \\
& \dot{S}_{2}\left(\varnothing_{r d}\right) S_{2}\left(\varnothing_{r d}\right)<0 \Rightarrow I_{s d n}=K_{\varnothing} \cdot \operatorname{sign}\left(S_{2}\left(\emptyset_{r d}\right)\right) .
\end{aligned}
$$


Direct current regulation

$\dot{S}_{4}\left(I_{s d}\right)=0 \Rightarrow$

$V_{\text {sdeq }}=\sigma L_{s} I_{\text {sdref }}+R_{s m} I_{s d}$

$\sigma L_{s} \omega_{s} I_{s q}-\frac{M_{s r}}{L_{r} T_{R}} \varnothing_{r d}$,

$R_{s m}=R_{s}+\frac{M_{s r}^{2} R_{r}}{L_{r}^{2}}$

$\dot{S}_{4}\left(I_{s d}\right) S_{4}\left(I_{s d}\right), 0 \Rightarrow V_{s d n}=K_{d} \operatorname{sign}\left(S_{4}\left(I_{s d}\right)\right)$.

\section{Speed regulation}

$\dot{S}_{1}(\omega)=0 \Rightarrow I_{\text {sqeq }}=$

$\frac{J \dot{\omega}_{r e f}+F w+T_{r}}{\frac{p M_{s r}}{L_{r}} \varnothing_{r d}}$,

$\dot{S}_{1}(\omega) S_{1}(\omega)<0 \Rightarrow I_{s q n}=K_{\omega} \cdot \operatorname{sign}\left(S_{1}(\omega)\right)$.

\section{Quadratic current regulation}

$$
\begin{aligned}
& \dot{S}_{3}\left(I_{s d}\right)=0 \Rightarrow \\
& V_{s q e q}=\sigma L_{s} i_{s q r e f}+R_{s m} I_{s q}+ \\
& \sigma L_{s} \omega_{s} I_{s d}+\frac{M_{s r}}{L_{r}} \omega \varnothing_{r d},
\end{aligned}
$$

$$
\dot{S}_{3}\left(I_{s q}\right) S_{3}\left(I_{s q}\right)<0 \Rightarrow V_{s q n}=K_{q} \cdot \operatorname{sign}\left(S_{3}\left(I_{s q}\right)\right) \text {. }
$$

The following gains $\left(K_{d}, K_{q}, K_{\varnothing}, K_{\omega}\right)$ should be chosen positive, to satisfy the stability condition of the system [12].

In the induction motor indirect field-oriented control (IFOC), we need the estimation of the rotor flux:

$$
\varnothing_{r d}=-\alpha R_{r} \varnothing_{r d}+\alpha M_{s r} R_{r} I_{s d}, \alpha=\frac{1}{L_{r}} .
$$

The mechanical equation of the estimated load torque is

$$
T_{r}=\frac{p M_{s r}}{L_{r}} \varnothing_{r d} I_{s q}-J \frac{d w}{d t}-F w .
$$

\section{RESULTS AND DISCUSSION}

The simulation results are given in order to check the PV system performances.

From Fig. (b-f) we verify the performance of the fuzzy MPPT technique. It improved the transient regime and reduced the fluctuations in the static state.

From the figures given above, we distinguish the effectiveness of sliding mode control combined with an intelligent tracking technique (fuzzy MPPT). Using the sliding mode we obtain a good speed tracking of its reference with a high stability, as well as a good robustness.

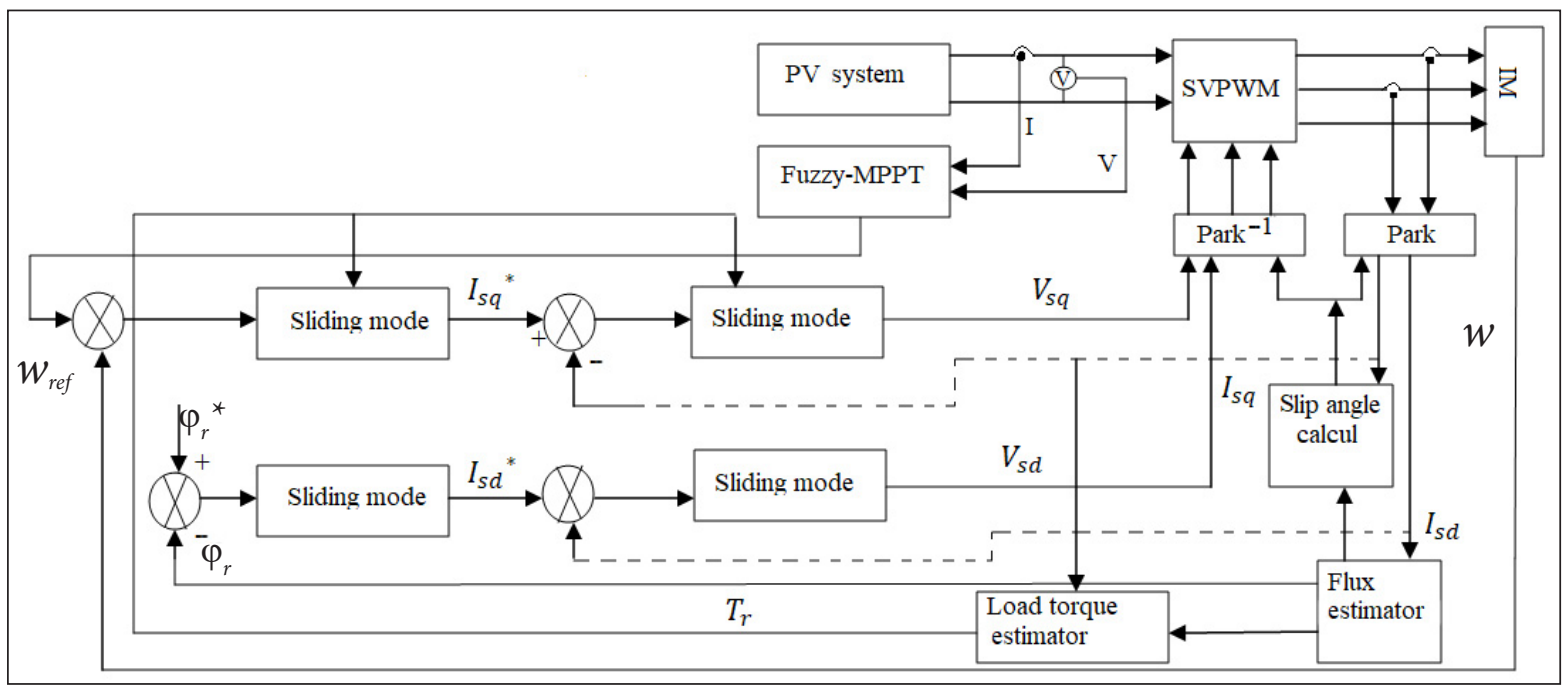

Fig. 17. A bloc structure diagram of the IM control 


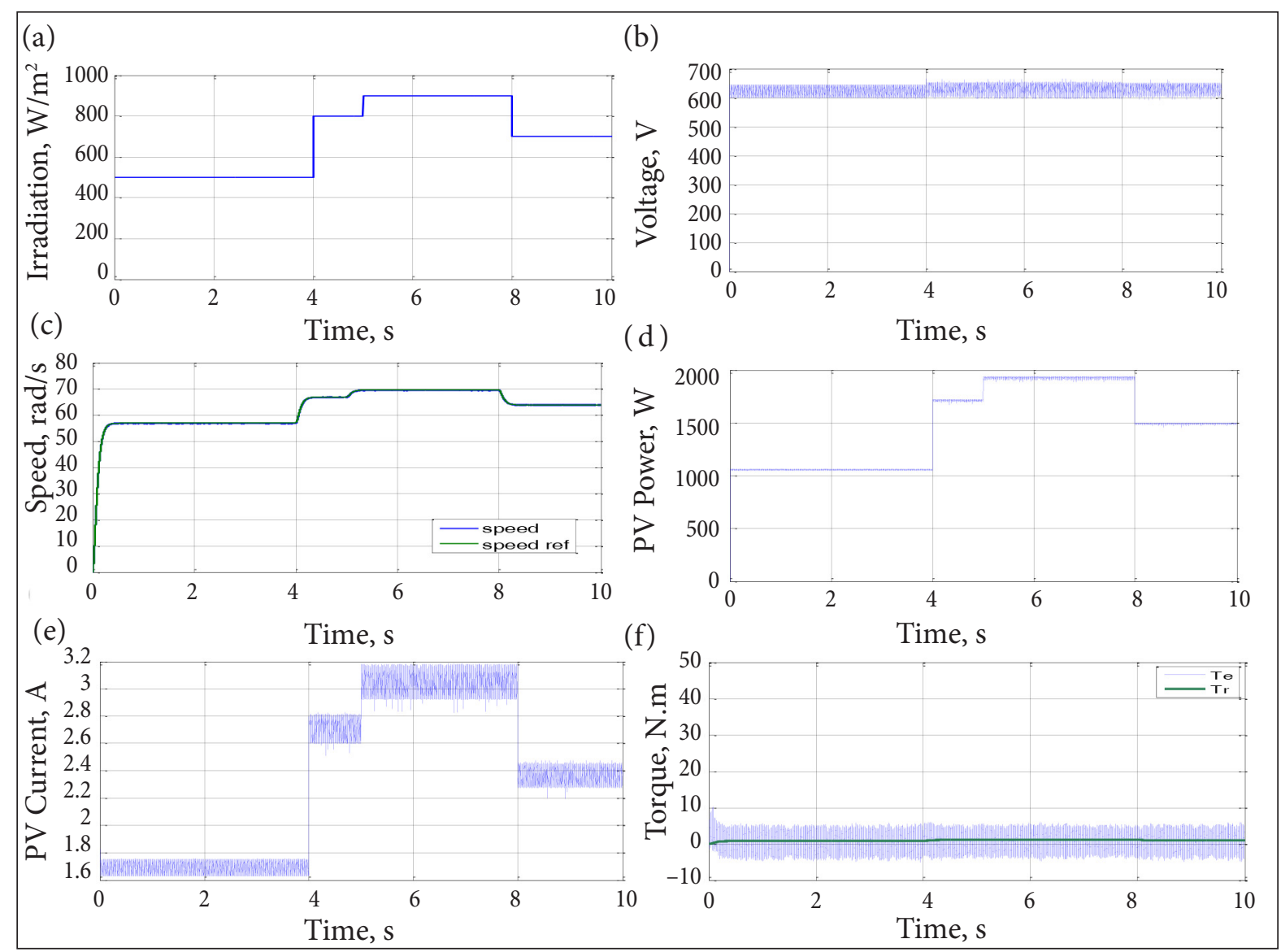

Fig. 18. PV system performances with variable irradiation

\section{CONCLUSIONS}

In order to improve the efficiency of the pumping system photovoltaic, we made the comparative study between two nonlinear structures order combined with an effective fuzzy MPPT approach: the classic control based on PI regulators, which depends on the machine parameters, and the cascaded sliding mode regulators to guarantee an independence to the parameters change. The simulation results show performance of the proposed structures. The first part of this study concerns the induction speed control. Figures 16(b) and 18(c) show the superiority of induction cascade sliding mode control where we notice a good speed tracking with a very short transitory mode, as well as a good robustness.

The second part concerns the MPPT strategy. From the curves representing the speed, torque and voltage we can distinguish the efficiency of the induction cascade sliding mode control with an intelligent tracking technique (fuzzy-MPPT), and we have better pursuit of the maximum point with a low ripple rate of voltage and power.

\section{Appendix}

We chose the model TE500, this generator statement is composed of 36 cells series-connected $\left(n_{s}=36\right)$.

Table 3. Photovoltaic panel parameters

\begin{tabular}{c|c|c}
\hline Maximal power & $P_{m}$ & $60 \mathrm{~W}$ \\
\hline $\begin{array}{c}\text { Voltage for maximal } \\
\text { power }\end{array}$ & $V_{p m}$ & $17.9 \mathrm{~V}$ \\
\hline $\begin{array}{c}\text { Current for maximal } \\
\text { power }\end{array}$ & $I_{p m}$ & $3.35 \mathrm{~A}$ \\
\hline Current of short circuit & $I_{c c}$ & $3.7 \mathrm{~A}$ \\
\hline $\begin{array}{c}\text { Voltage of open circuit } \\
\text { Temperature coefficient } \\
\left(I_{c c}\right)\end{array}$ & $V_{c o}$ & $22.5 \mathrm{~V}$ \\
\hline $\begin{array}{c}\text { System maximum } \\
\text { voltage }\end{array}$ & $V_{0}$ & $(0.065 \pm 0.015) \% /{ }^{\circ} \mathrm{C}$ \\
\hline
\end{tabular}


These data represent the typical performance of the panel TE500 measured with these outputs, and do not include the effect of additional equipment like the diodes and the cables. The data are based on the measures under the conditions standards SRC (Standard Reporting Conditions, also STC or Standard Test Conditions) which are as follows:

Illumination of $1 \mathrm{~kW} / \mathrm{m}^{2}$ (1 sun) to a spectrum AM 1.5;

Temperature of the cell $25^{\circ}$;

$K_{d}=500, K_{q}=500, K_{\varnothing}=400, K_{\omega}=300$;

$k_{p}=3.3 e^{-4}, k_{r}=3.3 e^{-4}, \eta_{c}=0.95, \eta_{m}=0.92$, $\eta_{p}=0.74$.

Table 4. Induction machine parameters

\begin{tabular}{cc}
\hline$R_{S}$ & $1.34 \Omega$ \\
\hline$R_{r}$ & $1.24 \Omega$ \\
\hline$M_{S R}$ & $0.17 \mathrm{H}$ \\
\hline$L_{r}$ & $0.18 \mathrm{H}$ \\
\hline$L_{S}$ & $0.18 \mathrm{H}$ \\
\hline$P$ & 2 \\
\hline$J$ & $0.0153 \mathrm{~kg} / \mathrm{m}^{2}$ \\
\hline$P$ & $1 \mathrm{~kW}$ \\
\hline
\end{tabular}

Received 24 February 2020 Accepted 20 March 2020

\section{References}

1. Bhattacharya M., Churchill S. A., Paramati S. R. The dynamic impact of renewable energy and institutions on economic output and $\mathrm{CO}_{2}$ emissions across regions. Renewable Energy Journal. 2017. Vol. 111. P. 157-167.

2. Ramesh G., Vasavi K., Sirisha S. L. Photovoltaic cell fed 3-phase induction motor using MPPT technique. International Journal of Power Electronics and Drive Systems (IJPEDS). 2014. Vol. 5. No. 2. P. 203-210.

3. Guisser M., El-Jouni A., Abdelmounim El. H. Robust sliding mode MPPT controller based on high gain observer of a photovoltaic water pumping system. IREACO Journal. 2014. Vol. 7. No. 2. P. 225-232.
4. Piegari L., Rizzo R., Spina I., Tricoli P. Optimized adaptive perturb and observe maximum power point tracking control for photovoltaic generation. Energies Journal. 2015. No. 8. P. 3418-3436.

5. Sharma C., Jain A. Performance comparison of PID and fuzzy controllers in distributed MPPT. International Journal of Power Electronics and Drive Systems (IJPEDS). 2015. Vol. 6. No. 3. P. 625-635.

6. Mehazzem F., Reama A. Comparative study of integral and classical backstepping controllers in IFOC of induction motor fed by voltage source inverter. International Journal of Hydrogen Energy. 2017. Vol. 42. No. 28. P. 17953-17964.

7. Zainal N. A., Apen A., Yusoff A. R. Modelling of photovoltaic module using Matlab Simulink. Proceedings of 2nd International Manufacturing Engineering Conference and 3rd Asia-Pacific Conference on Manufacturing Systems, Kuala Lumpur, Malaysia, 12-14 November 2015. Vol. 114. P. 1-9.

8. Kumar K. V., Michael P. A., John J. P., Kumar S. S. Comparative analysis of SPWM and SVPWM control for three phase inverter. ARPN Journal of Engineering and Applied Sciences. 2010. Vol. 5. No. 7. P. 61-74.

9. Delaleau E., Louis J. P., Ortega R. Modeling and control of induction motors. International Journal of Applied Mathematics and Computer Science. 2001. Vol. 11. No. 1. P. 105-129.

10. Sachin Jain S., Ramulu C., Padmanaban S., Ojo J. O., Ertas A. H. Dual MPPT algorithm for dual PV source fed open-end winding induction motor drive for pumping application. International Journal of Engineering Science and Technology. 2016. Vol. 19. No. 4. P. 1771-1780.

11. Pachauri R. K., Chauhan Y. K. Fuzzy logic controlled MPPT assisted PV-FC power generation for motor driven water pumping system. Proceedings of IEEE Students' Conference on Electrical, Electronics and Computer Science (SCEECS), Bhopal, India, 1-2 March 2014. P. 1-25.

12. Abdellatif Reama A., Mehazzem F., Cela A. Cascade Sliding Mode Control of a Field Oriented Induction Motor with Varying Parameters, 2011. https://www.intechopen.com 
Ines Zerimeche, Abdeslam Haouam,

Fateh Mehazzem, Khalil Nabti, Rachid Chenni

PROPORCINIO-INTEGRALINIO (PI) IR

KASKADINIO SLENKANČIOJO ALGORITMŲ

VALDIKLIO, REALIZUOTO PAGAL

ROTORIAUS MAGNETINIO SRAUTO

KRYPTI, PALYGINAMOJI STUDIJA, SKIRTA

FOTOVOLTINEI SIURBLIŲ SISTEMAI,

IR NERAIŠKIĄJA LOGIKA PAREMTO

MAKSIMALIOS GALIOS TAŠKO SEKIMO

OPTIMIZACIJA

\section{Santrauka}

Atlikta fotovoltinei siurblių sistemai skirta palyginamoji studija tarp proporcinio-integralinio (PI) ir kaskadinio slenkančiojo algoritmų, kurių veikimas realizuotas pagal rotoriaus magnetinio srauto kryptị. Saulès elektrinès maksimalios galios taško sekimo algoritme naudojama neraiškioji logika. Trifazis keitiklis valdomas SVPWM būdu - pulso pločio moduliacijos atmaina, charakterizuojama greitu reakcijos laiku ir žemais virpesiais. Pasiūlytas algoritmas puikiai veikia esant bet kokiai temperatūrai ir apšvietai. Modeliavimas ir rezultatų adekvatumo vertinimas atliekamas Matlab / Simulink programinio paketo aplinkoje. Iš gautų rezultatų matyti kaskadinio slenkančiojo valdymo su neraiškiąja logika pagrịstu MPPT privalumai.

Raktažodžiai: fotovoltinis generatorius, hidraulinių siurblių sistema, valdymas pagal rotoriaus magnetinio srauto krypti, PI reguliatoriaus, kaskadinis slenkantysis algoritmas, neraiškiąa logika pagrịstas MPPT 